\title{
Inpatient gout flare is multifactorial: comment on "clinical characteristics and risk factors for gout flare during the postsurgical period"
}

\author{
Kanon Jatuworapruki
}

Dear the editor,

I have read with great interest a paper on the characteristics and risk factors of postsurgical gout flare in people with comorbid gout by Jeong and Jeon [1]. The paper postulated that pre-surgical serum urate $\geq 9 \mathrm{mg} / \mathrm{dl}$ and postsurgical change of serum urate were associated with higher risk of postsurgical gout flare, while the use of any gout medication or allopurinol was associated with lower risk of postsurgical gout flare. Although this hypothesis is intuitively sound, the statistical analysis used in the study may not be adequate to support such assertions.

Inpatient gout flare is a multifactorial event influenced by a combination of gout-related (e.g., serum urate level, tophus) and hospitalization-related factors (e.g., diuretic adjustment, acute kidney injury, surgery) [2]. Surgery may be associated with gout flare through more than one mechanisms, including volume status change, tissue hypoxia and systemic inflammatory response [3, 4]. The current study analyzed the association between various factors and the occurrence of postsurgical gout flare using a univariate logistic regression. The univariate model puts a single covariate against the outcome of interest (postsurgical flare) without adjusting for potential confounders. The model also does not consider possible association between some factors. For example, it could be argued that 'allopurinol use' may be related to lower 'pre-surgical serum urate' or men may have higher 'pre-surgical serum urate'. These possible correlation cannot be adjusted for in a univariate analysis. Furthermore, the paper did not clarify the list of factors

Correspondence: kanon@tuac.th

Department of Medicine, Faculty of Medicine, Thammasat University, Pathumthani 12120, Thailand

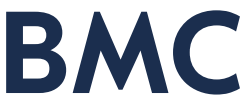

(c) The Author(s). 2020 Open Access This article is licensed under a Creative Commons Attribution 4.0 International License, which permits use, sharing, adaptation, distribution and reproduction in any medium or format, as long as you give appropriate credit to the original author(s) and the source, provide a link to the Creative Commons licence, and indicate if changes were made. The images or other third party material in this article are included in the article's Creative Commons licence, unless indicated otherwise in a credit line to the material. If material is not included in the article's Creative Commons licence and your intended use is not permitted by statutory regulation or exceeds the permitted use, you will need to obtain permission directly from the copyright holder. To view a copy of this licence, visit http://creativecommons.org/licenses/by/4.0/ 
Received: 23 June 2020 Accepted: 17 August 2020

Published online: 26 August 2020

\section{References}

1. Jeong $\mathrm{H}$, Jeon $\mathrm{CH}$. Clinical characteristics and risk factors for gout flare during the postsurgical period. Adv Rheumatol. 2019;59:31.

2. Jatuworapruk K, Grainger R, Dalbeth N, Taylor WJ. Development of a prediction model for inpatient gout flares in people with comorbid gout. Ann Rheum Dis. 2020;79:418-23.

3. Waldron JL, Ashby HL, Razavi C, et al. The effect of the systemic inflammatory response, as provoked by elective orthopaedic surgery, on serum uric acid in patients without gout: a prospective study. Rheumatology (Oxford). 2013;52:676-8.

4. Kang EH, Lee EY, Lee YJ, Song YW, Lee EB. Clinical features and risk factors of postsurgical gout. Ann Rheum Dis. 2008;67:1271-5.

\section{Publisher's Note}

Springer Nature remains neutral with regard to jurisdictional claims in published maps and institutional affiliations.

Ready to submit your research? Choose BMC and benefit from:

- fast, convenient online submission

- thorough peer review by experienced researchers in your field

- rapid publication on acceptance

- support for research data, including large and complex data types

- gold Open Access which fosters wider collaboration and increased citations

- maximum visibility for your research: over $100 \mathrm{M}$ website views per year

At BMC, research is always in progress.

Learn more biomedcentral.com/submissions 